\title{
Strategi Prospektif Pengembangan Dalam Ekowisata Waduk Cirata Yang Berkelanjutan
}

\author{
Purna Hindayani ${ }^{1 *}$, Armandha Redo Pratama1 ${ }^{1}$ Zuzy Anna ${ }^{2,3}$
}

${ }_{1}^{1}$ Program Studi Pendidikan Pariwisata, Fakultas Pendidikan Ilmu Pengetahuan Sosial, Universitas Pendidikan Indonesia, Jl. Dr. Setiabudi No.229, Isola, Kec. Sukasari, Kota Bandung, Jawa Barat, Indonesia;

2Program Studi Perikanan, Fakultas Perikanan dan Ilmu Kelautan Universitas Padjadjaran, Jl. Raya Bandung Sumedang KM 21, Jatinangor, Jawa Barat, Indonesia.

${ }^{3}$ Center for Sustainable Development Goals Studies, UNPAD SDGs Center, Gedung CISRAL UNPAD, Jl. Dipatiukur No. 46, Bandung 40132, Indonesia.

\begin{abstract}
ABSTRAK
Pengembangan ekowisata waduk Cirata memiliki potensi besar dalam penggerak perekomian dan membangun kesejahteraan masyarakat tanpa harus mengorbankan sumber daya alam dan merusak lingkungan bahkan berkelanjutan.Pada studi ini, ini bertujuan untuk menentukan variabel-variabel yang mempengaruhi pengembangan ekowisata di waduk Cirata serta mengetahui hubungan interdepensi antara variabel-variabel sehingga dapat dijadikan penentuan kebijakan dalam pengembangan ekowisata di waduk Cirata yang berkelanjutan. Metode yang digunakan adalah analisis struktural Matrix of Cross Impact Multiplication Applied to a Classification (MICMAC). Hasil penelitian menunjukan bahwa satu variabel penggerak yaitu konflik pemanfaatan waduk sedangkan variabel kunci terdapat 21 variabel dari 5 dimensi pembangunan keberlanjutan. Urutan prioritas variabel kunci pada dimensi lingkungan yaitu kualitas perairan; dimensi ekonomi terdapat tiga variabel yaitu peluang industri wisata, pengembangan ekonomi warga lokal (UMKM) dan alokasi pendanaan pariwisata; dimensi sosial terdapat dua variabel yaitu keterlibatan masyarakat lokal, peluang lapangan kerja bidang pariwisata; dimensi kelembangaan terdapat kesiapan regulasi dalam pengembangan ekowisata, dukungan pemerintah lokal, kesepakatan komunitas dan aturan lokal, koordinasi dan kolaborasi antar lembaga, dan dukungan pemerintah pusat; dimensi kepariwisataan tersapat 10 variabel yaitu aktivitas wisata, tata kelola dan manajemen pengelolaan wisata, keunikan dan keindahan di tempat wisata, sarana dan prasarana pariwisata, daya tarik wisata budaya dan alam, strategi promosi dan pemasaran, akomodasi wisata, aksebilitas wisata, potensi wisatawan lokal, dan potensi wisatawan asing. variabel-variabel tersebut menjadi pondasi awal dalam menentukan kebijakan oleh para pemangku kewenangan dalam pengelolaan ekowisata yang berkelanjutan di waduk cirata.
\end{abstract}

Kata kunci: waduk Cirata, ekowisata, variabel kunci, berkelanjutan

\begin{abstract}
The development ecotourism of Cirata reservoir has great potential in driving the economy building community welfare without having to sacrifice natural resources and damage the environment and even be sustainable. This study aims to determine the variables that influence the development of Cirata ecotourism and to determine the interdependence relationship between the variables so that it can be used as a policy for the sustainable development of Cirata ecotourism. The method used was Matrix Cross Impact Multiplication Applied to a Classification (MICMAC) structure analysis. The results showed that one driving variable is the conflict over the use of reservoirs, while the key variables are 21 of the 5 dimensions of sustainable development. A key variable in the environmental dimension, namely water quality; three key variables in the the economic dimension, namely tourism industry opportunities, economic development of local communities (MSMEs) and tourism funding allocations; two variables in the social dimension, namely the involvement of local communities, job opportunities in the tourism sector; the institutional dimension includes regulatory readiness in ecotourism development, local government support, community agreements and local rules, coordination and collaboration between institutions, and central government support; The dimensions of tourism included 10 variables, namely tourism activities, tourism management, uniqueness and beauty in tourist attractions, tourism facilities and infrastructure, cultural and natural tourist attractions, promotion and marketing strategies, tourism accommodation, tourism accessibility, potential local tourists, and potential foreign tourists. These variables become the initial foundation in determining policies and decisions by authorities in sustainable ecotourism management in the Cirata Reservoir
\end{abstract}

Keywords: Cirata resevoir, ecotourism, key variables, sustainability

Citation: Hindayani, P., Pratama, A.R, dan Anna, Z. (2021). Strategi Prospektif Pengembangan Dalam Ekowisata Waduk Cirata Yang Berkelanjutan. Jurnal Ilmu Lingkungan, 19(3), 620-629, doi:10.14710/jil.19.3.620-629

*Penulis korespondensi: purnahindayani@upi.edu 


\section{Pendahuluan}

Pada tahun 1988, Waduk Cirata merupakan waduk terbesar di Asia Tenggara, bertujuan dengan fungsi utama untuk pembangkit listrik yang memiliki luas $62 \mathrm{~km} 2$ dan volume 2.165 juta m3 yang mampu membangkitkan listrik dengan kapasitas terpasang 1.008 megawatt (MW) dan produksi pertahun mencapai 1.428 Gigawatt/Tahun untuk mensuplai kebutuhan listrik pulau Jawa dan Bali (Kholil \& Utomo, 2015; Kusumawardhani, 2017). Seiring dengan berjalanya waktu waduk dimanfaatkan di beberapa sektor terutama kegiatan perikanan budidaya dan perikanan tangkap (Z. Anna et al., 2017; Zuzy Anna, 2016; Nurhayati \& Herawati, 2018). Pemanfaatan waduk Cirata yang berkembang pesat adalah perikanan budidaya berupa karamba jarring apung (KJA). jumlah KJA pada awal beroperasi sebanyak 74 Unit, namun pada tahun 2017 bertambah menjadi 56.000-77.000 petak (Nurhayati \& Herawati, 2018; TM Pratiwi et al., 2020).

Sementara itu, menurut CESS UNPAD (2020) pada tahun 2019, jumlah KJA sebanyak 93.641 petak. Di sisi lain, Peraturan yang dikeluarkan oleh berdasarkan SuratKeputusan Gubernur Jawa Barat No. 660.31/Kep.923-DKP/2019, tentang Jumlah Keramba Jaring Apung (KJA) di Waduk Cirata, Waduk Saguling dan Waduk Jatiluhur yang Memenuhi Daya Dukung Lingkungan yang dibatasi dengan jumlah 7.204 petak KJA (untuk Waduk Cirata). waduk Cirata juga telah melebihi daya dukung dan daya tampung sehingga menimbulkan beban pencemaran yang tinggi yang akan berdampak pada keberlanjutan waduk itu sendiri(Sutjinurani \& Suharyanto, 2016).

Luasan waduk juga mengalami penurunan akibat kegiatan budidaya perikanan. Pada awalnya luasan waduk sekitar 6.200 hektar dengan rata-rata kedalaman air adalah 34,9 meter dan terletak pada ketinggian 225 meter dari permukaan laut (Soemarwoto et al., 1990) , kemudian pada tahun 2008 luasan waduk menurun menjadi 4.818 hektar (Nastiti et al., 2018) bahkan kedalaman waduk mengalami pendangkalan akibat penumpukan pakan di dasar perairan. Selain itu, menurut (Nastiti et al., 2018). Kondisi waduk Cirata yang saat ini pemanfaatanya di dominasi oleh perikanan KJA telah terjadi degradasi lingkungan yang dapat mencemari lingkungan Waduk Cirata, dimana jumlah keramba saat ini sudah melebihi daya dukung yang menyebabkan kelebihan hara yang dapat mencemari lingkungan dan dapat menyebabkan kematian ikan massal di Waduk Cirata setiap tahunnya. Pada kondisi tersebut, waduk Cirata tidak akan berkelanjutan yang sesuai dengan peruntukanya.

Pihak-pihak terkait termasuk Badan Pengelolaan Waduk Cirata (BPWC), akan melakukan penertiban jumlah KJA hingga 2023 agar waduk sesuai dengan daya tampung dan daya tampung serta berfungsi sesuai dengan peruntukanya. Upaya penertiban KJA di waduk Cirata juga merupakan upaya mendukung program pemerintah tentang Citarum Harum. Namun, penertiban KJA di waduk Cirata dikhawatirkan akan terjadi penurunan pada kuantitas hasil produksi perikanan yang nantinya para petani ikan akan mengalami kerugian bahkan kehilangan pekerjaan. Hal ini, pihak pemerintah dan para pemangku kepentingan akan menyusun solusi-solusi agar perekonomian para petani KJA tetap terjaga dengan konsep alih usaha. Konsep alih usaha yang dicanangkan diantaranya perubahan-perubahan teknologi budidaya yang lebih ramah lingkungan atau relokasi tempat budidaya ikan. Salah satu konsep alih usaha yang dicanangkan pemerintah diantaranya oleh Bupati Bandung Barat bahwa waduk Cirata akan direncanakan dalam mengembangkan kawasan wisata di sekitar Waduk Cirata khususnya di daerah Cipeundey (Pikiran Rakyat, 2018). Hal itu senada dengan pernyataan Kepala Bidang Pariwisata pada Dinas Pemuda Olahraga, Pariwisata, dan Kebudayaan (Disporaparbud) Kabupaten Purwakarta yaitu Irfan Suryana mengatakan, bahwa terdapat 2 waduk salah satunya waduk Cirata sangat potensial untuk dikembangkan jika penurunan KJA di waduk tersebut dilakukan sehingga kualitas air lebih baik, maka sangat berpotensi untuk pengembangan pariwisata (AyoPurwakarta.com, 2020). Selanjutnya, Perencanaan wisata ini diharapkan meningkatkan pendapatan asli daerah, dan dapat menggantikan usaha para petani ikan yang selama ini sebagai salah satu sumbangsih permasalahan lingkungan di waduk Cirata.

Disisi lain, Pada saat ini, waduk Cirata yang merupakan fungsi utama sebagai pembangkit listrik akan didirikan Pembangkit Listrik Tenaga Surya (PTLS) Terapung Waduk Cirata di Kabupaten Bandung Barat, Jawa Barat yang akan di bangun 2021 dan merupakan PLTS terapung pertama di Indonesia dan terbesar di ASEAN (Sunarya, 2020). Berkaitan dengan pembangunan PLTS tersebut, waduk Cirata bisa dijadikan daya tarik ekowisata. Konsep ekowisata menurut The International Ecotourism Society yang dimaksud mengartikan ekowisata sebagai perjalanan wisata alam yang bertanggungjawab dengan cara melakukan konservasi lingkungan dan meningkatkan kesejahteraan masyarakat lokal, selain itu memberikan nilai edukasi tidak hanya untuk wisatawan tetapi untuk pengelola wisata dan masyarakat lokal (TIES, 2015). Menurut Weaver (2001), ekowisata terdiri dari 3 unsur kunci yaitu (1) wisata yang focus pada atraksi pada lingkungan alam, (2) lebih menekankan pembelajaran sebagai bentuk interaksi wisatawan dengan alam, dan (3) harus berkelanjutan. Konsep pembangunan pariwisata yang memperhatikan adanya keseimbangan antara aspek kelestarian alam dan ekonomi adalah konsep ekowisata dan wisata minat khusus (Fandeli, 2002). Dengan demikian, ekowisata waduk Cirata akan dikembangkan sebagai pariwisata berkelanjutan yang memiliki keterpaduan dalam penggunaan berbagai sumber daya pariwisata yang mengedepankan pada aspek kelestarian alam dan 
kesejahteraan masyarakat tanpa mengindahkan aspek ekonomi (Prathama et al., 2020; Ruhanen et al., 2018).

Pariwisata merupakan salah satu sektor ekonomi yang pertumbuhan cepat untuk perkembangannya secara global bahkan termasuk Indonesia (Haryana, 2020; Ruhanen et al., 2018). Upaya dalam pengembangan ekowisata karena sektor pariwisata merupakan salah satu sektor nonmigas yang diharapkan dapat memberikan kontribusi yang cukup besar terhadap perekonomian lokal. Pada saat ini, Kawasan waduk Cirata berlokasi di antara tiga wilayah kabupaten, yaitu Kabupaten yaitu Kabupaten Purwakarta, Kabupaten Cianjur, dan Kabupaten Bandung Barat. para pemangku kepentingan utama dalam pengelolaan dalam mengembangan destinasi ekowisata di waduk Cirata. Dibutuhkan koordinasi dan kolaborasi dalam upaya pengembangan ekowisata di waduk Cirata. Selain itu, pengembangan ekowisata dapat terus menerus eksis dan berkelanjutan serta memberi manfaat dan dampak yang positif bagi wisatawan dan warga lokal. Upaya dalam pelaksaanaan pengembangan yaitu salah satunya dengan menentukan pemetaan tentang variabelvariabel kunci dari beberapa aspek dalam pembangunan berkelanjutan yang harus diperhatikan oleh pengambil kebijakan.

Dengan demikian, paper ini bertujuan untuk indentifikasi varabel-variabel strategis dalam menentukan ekowisata di waduk Cirata dengan cara mengambarkan intensitas pengaruh dan hubungan interdepensi antara variabel-variabel baik secara langsung dan tidak langsung. Selanjutnya, variabelvaribel tersebut diurutkan sesuai dengan tingkatan dari paling terpenting sampai sangat tidak penting. Diharapkan dengan hasil studi ini, varibel-variabel tersebut membantu para pemangku kepentingan dalam mengambil keputusan dapat menyususn strategi pengembangan pembangunan ekowsiata di waduk Cirata di masa yang akan datang.

\section{Metodologi}

Pada penelitian ini mengunakan analisa prospektif dengan analisis struktural yang bertujuan mencari variabel-variabel dan interelasi antarvariabel. Pengumpulan data dilakukan dengan wawancara in depth kepada para ahli yang berkecimpung dalam penelitian dan pengelolaan waduk Cirata baik dari akademisi, serta ahli di bidang lingkungan, perairan, perikanan, sosiologi, geografi dan ekonomi sumberdaya alam dan lingkungan.

Menurut Fauzi (2019) analisis struktural merupakan "tool" yang dirancang untuk menghubungan ide-ide sehingga mampu menentukan variabel-variabel yang esensial dalam suatu ekosistem. Salah satunya tool yaitu dengan mengunakan perangkat lunak MICMAC. Metode Analisis struktural dengan metode MICMAC digunakan untuk menentukan klasifikasi variabel, yang bertujuan untuk menyusun ide-ide untuk menghadapi pengambilan keputusan yang kompleks dan membantu perencana dan pembuat kebijakan merumuskan strategi berbasis masa depan (Ariyani \& Fauzi, 2019; Nematpour et al., 2020; Noorizadeh et al., 2020; Yanuar et al., 2018).

Analisis data pada penelitian ini mengunakan analisis struktural yang merupakan salah satu alat dalam pendekatan sistem dengan mengunakan software MICMAC. Analisis mengunakan Metode MICMAC (Cross Impact Matrix Multiplication Aplied to Classification). metode struktural dengan alat bantu MICMAC akan mengelompokan dan menentukanan hierarki variabel strategis dari suatu sistem serta mengetahui pengaruh timbal baliknya. Selanjutnya, analisis prospektif ini bermanfaat dalam proses pengambilan kebijakan karena akan mengarahkan fokus dari kebijakan, dan menghindari variabelvariabel yang tidak relevan sehingga mengakibatkan kegagalan.

Adapun prisip mengunakan MIC MAC, menurut de Almeida \& de Moraes, (2013) dan Fauzi (2019) yaitu 1. Indentifikasi variabel-variabel utama yang bersifat influential (mempengaruhi) dan dependent (dipengaruhi) yang esensial bagi sistem., 2. Memetakan hubungan antarvariabel dan relevansi variabelvariabel tersebut dalam menjelaskan suatu sistem., 3 . Mengungkapkan rantai sebab akibat dari suatau sistem, didalam MICMAC variabel dikelompokan kedalam empat kuadran berdasarkan kategori ketergantungan (dependence) dan pengaruh (Influence) yang disajikan pada Gambar 1.

\section{Hasil dan Pembahasan}

\subsection{Variabel-variabel Penentu Pengembangan Ekowisata Waduk Cirata}

Pada studi ini dilakukan wawancara mendalam dengan para berbagai pakar yang relevan. Selanjutnya, literatur dan studi terkait pengembangan ekowisata di waduk Cirata juga di analisis dan divalidasi. Menurut Fauzi (2019) analisis struktural atau variabel merupakan langkah awal yang penting dalam menganalisis keberlanjutan (Fauzi, 2019).

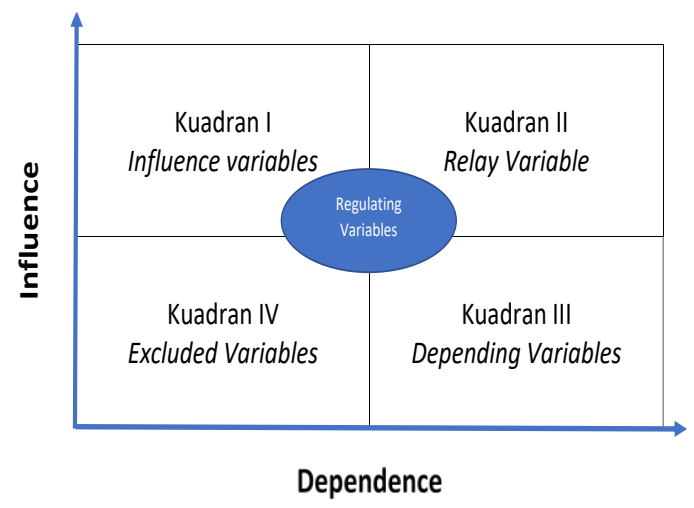

Gambar 1. Pemerataan dalam MIC MAC 
Tabel 1. Variabel-Variabel Pengembangan Ekowisata Waduk Cirata Berdasarkan Dimensi

\begin{tabular}{|c|c|c|c|c|}
\hline Dimensi Lingkungan & Dimensi Ekonomi & Dimensi Sosial & Dimensi Kelembagaan & Dimensi Kepariwisataan \\
\hline $\begin{array}{l}\text { - Konservasi Perairan } \\
\text { (L1) } \\
\text { - Daya Dukung } \\
\text { Lingkungan (L2) } \\
\text { - Kualitas Perairan } \\
\text { (L3) } \\
\text { - Konservasi } \\
\text { Sumberdaya Alam } \\
\text { (Perikanan Tangkap) } \\
\text { (L4) } \\
\text { - Jumlah Pengurangan } \\
\text { KJA (L5) } \\
\text { - Luasan Gulma Air } \\
\text { (L6) } \\
\text { - Ancaman Bencana } \\
\text { (L7) } \\
\text { - Frekuensi Turn } \\
\text { Over/ Upwelling (L8) }\end{array}$ & $\begin{array}{l}\text { - Peluang Industri } \\
\text { Wisata (E1) } \\
\text { - Peningkatkan } \\
\text { Retribusi Daerah } \\
\text { (E2) } \\
\text { - Peningkatkan } \\
\text { Pendapatan Warga } \\
\text { Lokal (E3) } \\
\text { - Kewirausahaan } \\
\text { Atau Kepemilikan } \\
\text { Bidang Pengelola } \\
\text { Wisata oleh Warga } \\
\text { Lokal (E4) Pengan } \\
\text { - Pengembangan } \\
\text { Ekonomi Warga } \\
\text { Lokal (UMKM) (E5) } \\
\text { - Willingness To Pay } \\
\text { untuk Konservasi } \\
\text { Perairan (E6) } \\
\text { - Alokasi Pendanaan } \\
\text { Pariwisata (E7) }\end{array}$ & $\begin{array}{l}\text { - Keterlibatan Masyarakat } \\
\text { Lokal (S1) } \\
\text { - Tingkat Kesejahteraan } \\
\text { Warga Lokal (S2) } \\
\text { - Peluang Lapangan Kerja } \\
\text { Bidang Pariwisata (S3) } \\
\text { - Konservasi Budaya (S4) } \\
\text { - Konflik Kepentingan } \\
\text { Pemanfaatan Waduk (S5) }\end{array}$ & $\begin{array}{l}\text { - } \text { Dukungan } \\
\text { Pemerintah Pusat } \\
\text { (K1) } \\
\text { - Dukungan } \\
\text { Pemerintah Lokal } \\
\text { (K2) } \\
\text { - Dukungan dan } \\
\text { Kesepakatan } \\
\text { Komunitas dan } \\
\text { Aturan Lokal (K3) } \\
\text { - Kesiapan Regulasi } \\
\text { dalam } \\
\text { Pengembangan } \\
\text { Ekowisata/ Daerah } \\
\text { Tujuan Wisata (K4) } \\
\text { - Koordinasi dan } \\
\text { Kolaborasi Antar } \\
\text { Lembaga (K5) }\end{array}$ & $\begin{array}{l}\text { - Aksebilitas Wisata } \\
\text { (P1) } \\
\text { - Daya Tarik Wisata } \\
\text { Budaya Dan Alam } \\
\text { (P2) } \\
\text { - Aktivitas Wisata } \\
\text { (P3) } \\
\text { - Akomodasi Wisata } \\
\text { (P4) } \\
\text { - Potensi Wisatawan } \\
\text { Lokal (P5) } \\
\text { - Potensi Wisatawan } \\
\text { Asing (P6) } \\
\text { - Tata Kelola dan } \\
\text { Manajemen } \\
\text { Pengelolaan Wisata } \\
\text { (P7) } \\
\text { - Sarana } \\
\text { Prasarana dan } \\
\text { Pariwisata (P8) } \\
\text { - Strategi Promosi } \\
\text { Dan Pemasaran (P9) } \\
\text { - Keunikan r dan } \\
\text { Keindahan di } \\
\text { Tempat Wisata } \\
\text { (P10) }\end{array}$ \\
\hline
\end{tabular}

Direct influence/dependence map

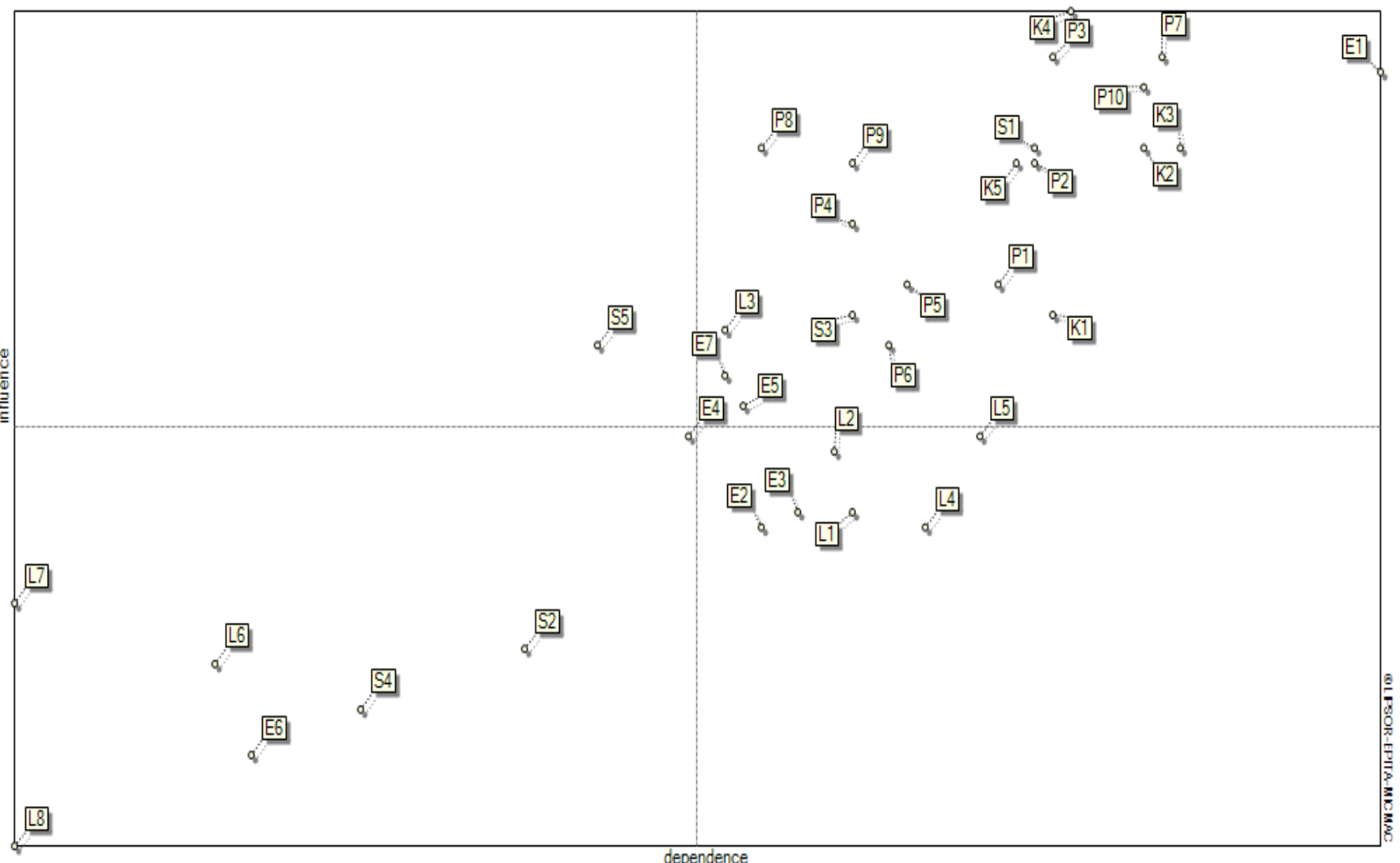

Gambar 2. Peta variabel pengembangan ekowisata waduk Cirata berdasarkan pengaruh dan ketergantungan 
Tahap pertama ialah mengindetifikasi variabel, hasil menunjukan 35 variabel dalam pengembangan ekowisata di waduk Cirata. Variabel-variabel tersebut dikelompokan ke dalam beberapa dimensi dimulai dari dimensi lingkungan, dimensi ekonomi, dimensi keberlanjutan sosial, dimensi kelembagaan dan dimensi kepariwisatan itu sendiri. Variabel-variabel tersebut dikelompokkan dalam lima dimensi untuk pembangunan ekowisata waduk Cirata yang berkelanjutan. Berikut merupakan variabel-variabel yang disajikan pada Tabel 1.

Variabel-variabel tersebut, ditentukan dengan skala peringkatan antara dalam pengembangan ekowisata yang berkelanjutan di waduk Cirata. Tahapan selanjutnya yaitu menjelaskan hubungan antara variabel melalui software MICMAC sehingga dapat menentukan variabel kunci. Hasil Analisa disajikan pada Tabel 2 .

\subsection{Penentu variabel-variabel kunci pada pengambangan ekowisata di waduk Cirata}

Kuadran I merupakan variabel input atau variabel penggerak yang memiliki ciri pengaruh yang kuat. Kuadran II merupakan variabel kunci atau variabel kontrol atau relay variabel, yang memiliki pengaruh yang kuat dan ketergantungan yang kuat. Kuadran III merupakan wilayah variabel keluaran (output), mempunyai ciri variabel yang sangat ketergantungan dan pengaruh sedikit. Kuadran IV merupakan "excluded variables" atau variabel autonomous yang dicirikan pengaruh sangat kecil dan ketergantungan sangat kecil, pada kuandran ini akan langsung dikelurkan dari sistem karena tidak akan menghetikan kerjanya sebuah sistem.

Pada studi ini, hasil menunjukan beberapa variabel-variabel yang penting dalam pengembangan ekowisata di waduk Cirata, yang dapat sebagai pendorong serta kunci dalam strategi pembangunan pariwisata yang berkelanjutan dalam jangka panjang. Hasil dari analisa variabel-variabel bertujuan untuk mengambil keputusan dalam perencanaan pengembangan wisata di waduk Cirata dan menentukan variabel-variabel yang menjadi prioritas yang harus segera dikembangan oleh pemerintah setempat dan para stakeholder, para perencana dan pembuat kebijakan perlu secara khusus memperhatikan pada kudran I dan II. Hasil variabelvariabel kunci diidentifikasi sebanyak 22 Variabel pada kuadran I dan kuadran II.

Pada kuadran I, merupakan variabel input atau variabel determinan atau variabel penggerak, hasil dari MICMAC menunjukan hanya satu variabel yaitu variabel konflik kepentingan pemanfaatan waduk (K5) pada dimensi sosial. Variabel konflik kepentingan pemanfaatan waduk akan menjadi pendorong utama dalam menentukan pengembangan ekowisata di waduk Cirata. Variabel tersebut merupakan permasalahan yang krusial pengunanaan 624 kawasan waduk Cirata di berbagai sektor termasuk pariwisata, terutama kewenangan-kewenangan dalam pemanfaatan waduk khususnya untuk dalam penetapan regulasi ekowisata perlu segera direalisasikan agar tidak terjadi tumpang tindih pemanfaatan waduk serta konflik di masa yang akan datang. Pada saat ini, perizinan di masing-masing sektor berbeda beda izin dan regulasi di masingmasing kelembagaan. Padahal, kelembagaan merupakan komponen yang dapat mempengaruhi keberlangsungan berjalannya suatu sistem, termasuk di dalamnya konteks pemanfaatan waduk Cirata sebagai sumber pengelolaan air dan pembangkit listrik di Jawa Barat. Di dalamnya diperlukan koordinasi antar aktor kelembagaan baik pusat, daerah kabupaten maupun kota, BUMN yang terlibat untuk mendapatkan suatu kesatupaduan langkah dan tindakan pencapaian tujuan bersama dalam mengembangakan ekowisata di daerah tersebut.

Pada kuadran II merupakan variabel yang sensitif dan sangat tidak stabil dalam pengembangan ekowisata di waduk Cirata, jika ada intervensi pada variabel ini maka akan berpengaruh terhadap sistem secara keseluruhan. Pada dimensi lingkungan yang harus diperhatikan adalah kualitas air, bahkan kualitas air di waduk Cirata telah mengalami kerusakan yang parah dan telah mengalami kondisi degradasi lingkungan bahkan sudah berada pada kondisi eutrofik menuju hipertrofik yang berarti telah mencapai kondisi perairan tercemar (Nastiti et al., 2018; TM Pratiwi et al., 2020). Sementara itu, kualitas air peruntukan untuk sarana dan prasarana rekreasi air atau pariwisata berbasis tirta adalah kelas dua yang sesuai dengan PP 22 Tahun 2021 tentang baku mutu kualitas air. Oleh karena itu, dimensi lingkungan pada variabel kualitas air untuk pengembangan waduk Cirata harus diperhatikan. Upaya perbaikan kualitas air di waduk Cirata secara langsung maupun tidak langsung merupakan upaya memperbaiki daya dukung lingkungan, konservasi air, pengurangan KJA dapat memperbaiki kualitas air, membersihkan gulma seperti eceng gondok sebagai upaya pembersihan jalur transportasi air sekaligus dalam memperbaiki kualitas air.

Pada dimensi ekonomi yang menjadi variabel kunci yaitu variabel peluang industri pariwisata (E1), pengembangan ekonomi warga lokal (UMKM) (E5) dan alokasi pendanaan pariwisata (E7). Peluang industri pariwisata tirta di waduk Cirata sangat potensial mengingat program SK Gubernur Provinsi Jawa Barat terkait pengurangan KJA di waduk Cirata dari 98.000 petak dan rencana disisakan sebanyak 7.000 petak pada tahun 2023. Penurunan KJA akan berpengaruh pada kualitas perairan waduk Cirata sehingga diharapkan bisa sesuai dengan peruntukanya dan dapat mengembangan sektor pariwisata. Variabel Pengembangan Ekonomi Warga Lokal (UMKM) dan alokasi pendanaan pariwisata perlu diperhatikan, jika kebijakan pembangunan 
pariwisata dalam meningkatkan ekonomi lokal melalui UMKM dengan pemasaran produk yang khas seperti oleh-oleh khas setempat, merupakan upaya strategis dalam rangka mewujudkan kesejahteraan masyarakat. Namun, program-program pengembangan ekonomi lokal berbasis UMKM perlu pendanaan untuk meningkatan sektor UMKM dilakukan berbagai program seperti kemudahan dalam permodalan, fasilitasi pengembangan UMKM, pelatihan manajemen dan kewirausahaan serta pelatihan lainnya untuk warga setempat.

Pada dimensi sosial terdapat dua variabel kunci yaitu keterlibatan masyarakat lokal (S1) dan peluang lapangan kerja di bidang pariwisata (S3).
Keterlibatan masyarakat lokal yang dimaksud keikutsertaan dan terlibat secara aktif masyarakat yang ada di sekitar waduk Cirata dalam pengembangan industri pariwisata termasuk pengembangan UMKM, pengembangan industri ekowisata di waduk Cirata kedepanya mampu memberikan lapangan pekerjaan baru atau pekerjaan subtitusi dari sebelumnya petani KJA sehingga secara tidak langsung dapat mensejahteraan masyarakat lokal. Tidak hanya mengembangkan UMKM yang berkaitan dengan sektor pariwisata tetapi variabel peluang lapangan kerja pariwisata lainnya bisa dikembangan.

Tabel 2. Hasil analisis variabel pengembangan ekowisata waduk Cirata

\begin{tabular}{llc}
\hline Kuadran & Hasil Analisis Variabel & Dimensi \\
\hline
\end{tabular}

\begin{tabular}{|c|c|c|}
\hline \multirow{21}{*}{ II (intermediate/key variables) } & Peluang Industri Pariwisata & Ekonomi \\
\hline & Pengembangan Ekonomi Warga Lokal (UMKM) & Ekonomi \\
\hline & Alokasi Pendanaan Pariwisata & Ekonomi \\
\hline & Kualitas Perairan & Lingkungan \\
\hline & Keterlibatan Masyarakat Lokal & Sosial \\
\hline & Peluang Lapangan Kerja Bidang Pariwisata & Sosial \\
\hline & Dukungan Pemerintah Pusat & Kelembagaan \\
\hline & Dukungan Pemerintah Lokal & Kelembagaan \\
\hline & Dukungan dan Kesepakatan Komunitas dan Aturan Lokal & Kelembagaan \\
\hline & $\begin{array}{l}\text { Kesiapan Regulasi dalam Pengembangan Ekowisata/ Daerah Tujuan } \\
\text { Wisata }\end{array}$ & Kelembagaan \\
\hline & Koordinasi dan Kolaborasi antar Lembaga & Kelembagaan \\
\hline & Aksebilitas Wisata & Pariwisata \\
\hline & Daya Tarik Wisata Budaya dan Alam & Pariwisata \\
\hline & Aktivitas Wisata & Pariwisata \\
\hline & Akomodasi Wisata & Pariwisata \\
\hline & Potensi Wisatawan Lokal & Pariwisata \\
\hline & Potensi Wisatawan Asing & Pariwisata \\
\hline & Tata Kelola dan Manajemen Pengelolaan Wisata & Pariwisata \\
\hline & Sarana Dan Prasarana Pariwisata & Pariwisata \\
\hline & Strategi Promosi Dan Pemasaran & Pariwisata \\
\hline & Keunikan Dan Keindahan Di Tempat Wisata & Pariwisata \\
\hline \multirow{6}{*}{ Kuadran III (output/dependent variables) } & Konservasi Perairan & Lingkungan \\
\hline & Daya Dukung Lingkungan & Lingkungan \\
\hline & Jumlah Pengurangan KJA & Lingkungan \\
\hline & Konservasi Sumber Daya Alam (Perikanan Tangkap) & Lingkungan \\
\hline & Peningkatan Retribusi Daerah & Ekonomi \\
\hline & Peningkatan Pendapatan Warga Lokal & Ekonomi \\
\hline \multirow{6}{*}{ Kuadran IV (excluded variables) } & Tingkat Kesejahteraan Warga Lokal & Sosial \\
\hline & Konservasi Budaya & Sosial \\
\hline & Willingness to Pay untuk Konservasi Perairan & Ekonomi \\
\hline & Luasan Gulma Alr & Lingkungan \\
\hline & Ancaman Bencana Alam & Lingkungan \\
\hline & Frekuensi Turn Over/Upwelling & Lingkungan \\
\hline
\end{tabular}


Dimensi kelembagaan terdapat 5 variabel kunci yaitu baik dukungan pemerintah pusat (K1) maupun dukungan pemerintah lokal (K2), dukungan komunitas dan aturan lokal (K3), kesiapan regulasi dalam pengembangan ekowisata sebagai daerah tujuan wisata (K4) di waduk Cirata serta koordinasi dan kolaborasi antar Lembaga (K5). Waduk Cirata berlokasi di 3 kabupaten yaitu Kabupaten Bandung Barat, Kabupaten Cianjur dan Kabupaten Purwakarta. Kelembagaan yang ikut serta dalam pengunaan perairan umum di Waduk Cirata cukup banyak yang terlibat. pengelolaan waduk Cirata untuk kegiatan pembangkit listrik oleh PT PJB Unit Pembangkitan (UP) Cirata, kelembagaan lokal yaitu Masyarakat Peduli Cirata (MPC), kelembagaan pemerintah dalam pemanfaatan perikanan budidaya seperti Dinas Kelautan dan perikanan Provinsi, kelembagaan lainya seperti Badan Pengelola Waduk Cirata (BPWC). Upaya dalam mengembangan ekowisata di waduk Cirata perlu melibatkan dan dukungan pusat dan daerah baik tingkat provinsi maupun Baupaten/kota. Kelembagaan pemerintah di bidang pariwisata baik tingkat kabupaten dan tingkat provinsi belum bisa mengembangkannya terkait kewenangannya, hal ini di paparkan oleh Kepala Bidang Pariwisata pada Dinas Pemuda Olahraga, Pariwisata, dan Kebudayaan (Disporaparbud) Kabupaten Purwakarta Irfan Suryana di dalam artikel (AyoPurwakarta.com, 2020).

Dalam pengembangan Waduk Cirata sebagai destinasi ekowisata unggulan perlu koordinasi dan kolabarasi agar terintegrasi satu sama lain dan perlu pemahamanan yang mendasar tentang ekowisata yang akan dikembangkan. Upaya koordinasi dan kolaborasi dari pihak berkewenangan baik pusat maupun daerah. Koordinasi dan kolaborasi merupakan variabel kunci untuk memetakan permasalah yang eksisting dalam rangka upaya pengelolaan yang terintegrasi di waduk Cirata tanpa merugikan atau mengorbankan sektor lainnya. Untuk merealisasi pengembangan ekowisata yang melibatkan berbagai pihak penyelanggara yang ditunjuk pemerintah pusat dalam pengelolaan waduk Cirata, kelembangaan pemerintah daerah baik provinsi dan kabupaten, komunitas masyarakat di sekitar waduk Cirata dan kelembagaan laiinya harus segera dilakukan diskusi atau FGD, dalam hal ini terintegrasi dengan perencanaan pembangunan ekowisata di waduk Cirata. Upaya-upaya tersebut harus diperkuat dengan kesiapan regulasi kepariwisataan terkait daerah tujuan ekowisata di waduk Cirata terutama menentukan zonasi-zonasi untuk aktivitas kepariwisataan.

Dimensi kepariwisataan terdapat 10 variabel strategis yang menjadi variabel kunci yang artinya keseluruhan dimensi ini penting untuk dikembangkan. Adapun hasil Analisa oleh MICMAC bahwa urutan peringkat dari kesepuluh tersebut yang prioritas dikembangakan yaitu : 1 . Aktivitas wisata (P3) 2. Tata Kelola Dan Manajemen Pengelolaan
Wisata (P7); 3. Keunikan Dan Keindahan Di Tempat Wisata (P10); 4. Sarana dan Prasarana Pariwisata (P8); 5. Daya Tarik Wisata Budaya dan Alam (P2); 6. Strategi Promosi Dan Pemasaran (P9); 7. Akomodasi Wisata (P4) 8. Aksebilitas Pariwisata (P8); 9. Potensi Wisatawan Lokal (P5) dan 10. Potensi Wisatawan Asing (P6). Urutan 3 variabel kunci pertama adalah aktivitas wisata, tata kelola dan manajemen pengelolaan wisata, keunikan dan keindahan di tempat wisata segera dikembangkan. Di dalam tata pengelolaan pariwisata di waduk Cirata tentunya harus matang dari sisi regulasi ekowisata, kelembangaan dan koordinasi sehingga dapat menghindari konflik pemanfaatan di waduk Cirata di masa yang akan datang. Pemanfaatan waduk Cirata yang peruntukan pertama adalah sebagai pembangkit listrik namun kenyataan dilapangan masih terdapat konflik pemanfaatan waduk tersebut salah satunya sektor perikanan budidaya yang telah melebihi daya tampung. Sementara itu, sektor pariwisata masih belum optimal terutama fasilitas sarana dan prasarana belum mendukung. Potensi ekowisata di waduk Cirata masih belum dikembangkan hingga saat ini, padahal sektor yang ecofriendly industry karena dapat memacu ekonomi kreatif akan tetapi konsep ekowisata di waduk Cirata masih sebatas ide.

Berdasarkan pengamatan dilapangan, pada saat ini aktivitas pariwisata belum kearah ekowisata. pernyataan ini diperkuat dengan penelitian dari Purwanto et al., (2016) bahwa pengelolaan waduk Cirata masih konvensional, restoran yang mengapung tidak mengikuti konsep ekowisata, keamanan wisatawan yang masih belum dipetimbangan seperti overkapasitas di perahu. Pengelolaan wisata Cirata yang tidak efektif dikhawatirkan akan berdampak negatif terhadap lingkungan, berdampak kepada kultur lokal, mengurangi peranan masyarakat lokal dan persaingan usaha dimana pada saat ini Beberapa bisnis pariwisata datang dari luar bukan dari masyarakat sekitar (Purwanto et al., 2016). Keunikan dan keindahan waduk Cirata sudah memilikinya, bendungan Cirata, wisata tirta maupun wisata agro, keindahan sumberdaya alam. Wisatawan tidak hanya bertanggung jawab terhadap sumberdaya alam dan tidak merusak tetapi juga mendapatkan nilai edukasi dari waduk Cirata yang merupakan PLTA dan Pembangkit listrik tenaga surya terbesar di ASEAN. Pengembangan ekowisata di waduk Cirata harus mengembangkan kearifan lokal berupa kesenian setempat, kegotongroyongan, gastronomi makanan sunda, memperhatikan keselamatan wisatawan, daya tarik wisata alam.

Pada kuadran III, variabel pada kuadran ini merupakan variabel yang sensitive jika terjadi perubahan pada variabel di kuadran I dan II. Variabel ini merupakan output atau variabel yang terdampak dari variabel pada kuadran I dan Kuadran II. Berdasarkan hasil Analisa MICMAC, terdapat 6 variabel yaitu 4 variabel dimensi lingkungan yaitu 
konservasi perairan (L1), daya dukung lingkungan (L2), jumlah pengurangan KJA (L5), konservasi sumber daya alam (perikanan tangkap) (L4), dan 2 variabel Ekonomi yaitu Peningkatan Retribusi Daerah (E3) dan Peningkatan Pendapatan Warga Lokal (E2).

Adapun hasil jaringan pengaruh secara langsung antar variabel yang disajikan pada Gambar 3 . Variabel yang bedasarkan tingkat pengaruh yang paling tinggi adalah kesiapan regulasi pengembangan ekowisata atau saerah tujuan wisata di waduk Cirata. Hasil studi ini merupakan dasar penentu yang kuat bagi seluruh pihak yang terlibat dalam pengambilan keputusan dan kebijakan terutama pada variabel di kuadran I dan kuadran II yang mempunyai pengaruh kuat terhadap variabel-variabel lainnya. Hasil dari pengembangan ekowisata di waduk Cirata akan diprediksi akan memberikan dampak baik secara langsung maupun tidak langsung.

Pada Tabel 3., berdasarkan tingkat pengaruh secara langsung untuk menentukan prioritas dari variabel pengerak pada kaudran I dan variabel kunci pada kuadran II yang mana harus dikembangkan dan menjadi prioritas dimulai urutan 1 dan urutan 22 . variabel pada kuadran I dan Kuadran II yang menjadi perhatikan dan menjadi dasar penentu kebijakan. Penentuan variabel ini tentunya perlu kebijakan dan program yang terintegrasi terkait dengan pengembangan ekowisata di waduk Cirata dan diharapkan ada tindak lanjut dari studi ini.

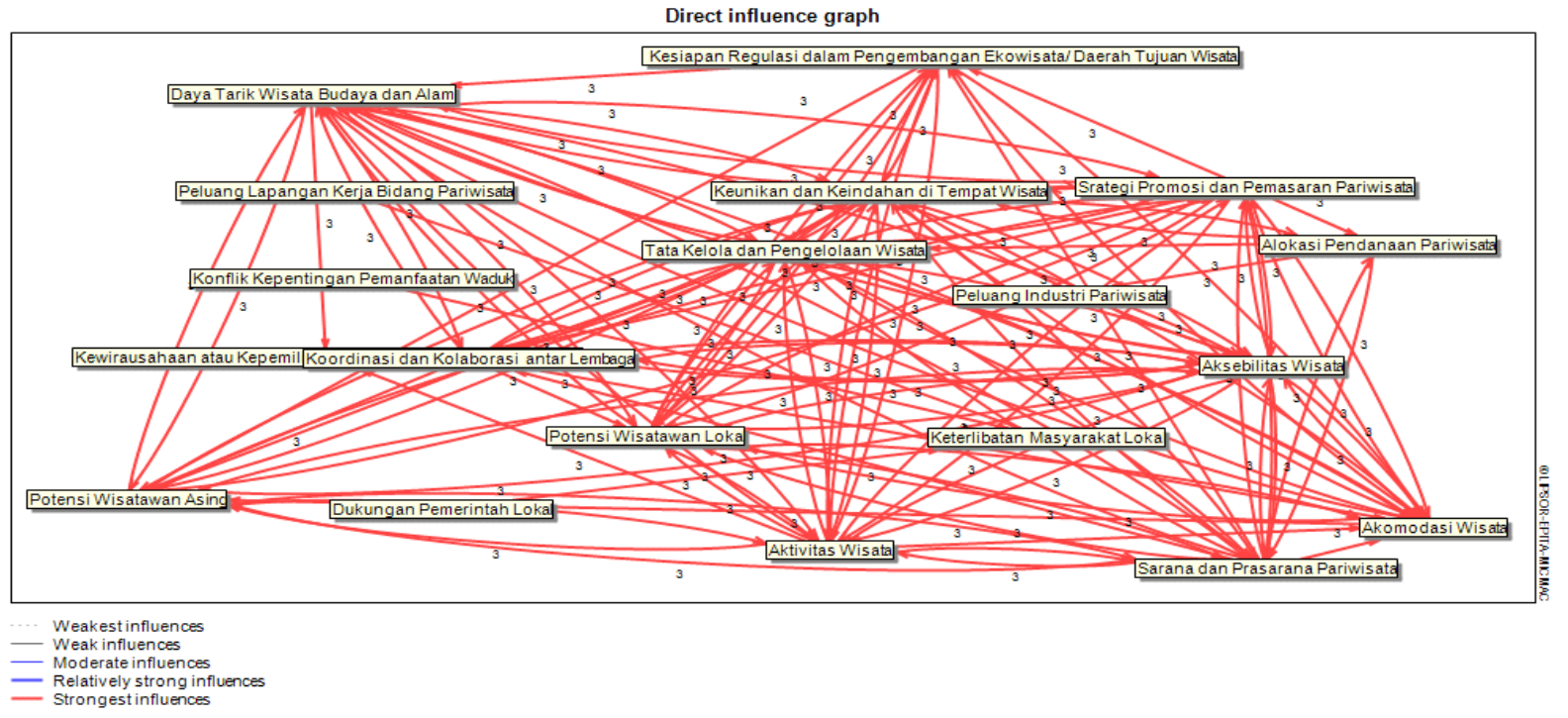

Gambar 3. Hubungan pengaruh langsung antarvariabel

Tabel 3. Peringkat Variabel Berdasar Tingkat Pengaruh Langsung

\begin{tabular}{|c|c|c|c|c|c|}
\hline Peringkat & Kode & Variabel & Peringkat & Kode & Variabel \\
\hline & $K 4$ & Kesiapan Regulasi Dalam Pengembangan & 19 & 55 & Konflik Kepentingan Pemanfaatan Waduk \\
\hline $\begin{array}{l}1 \\
2\end{array}$ & $\begin{array}{l}\text { K4 } \\
\text { P3 }\end{array}$ & $\begin{array}{l}\text { Ekowisata/ Daerah Tujuan Wisata } \\
\text { Aktivitas Wisata }\end{array}$ & $\begin{array}{l}19 \\
20\end{array}$ & $\begin{array}{l}35 \\
\mathrm{P} 6\end{array}$ & Petenci Wlicatawan Asino \\
\hline & & Tata Kelola Dan Manajemen Pengelolaan & & & 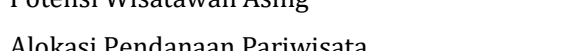 \\
\hline 3 & P7 & Wisata & 21 & E7 & AIokası Pendanaan Parıwisata \\
\hline 4 & E1 & Peluang Industri Wisata & 22 & E5 & $\begin{array}{l}\text { Pengembangan Ekonomi Warga Lokal } \\
\text { (Umkm) }\end{array}$ \\
\hline 5 & P10 & Keunikan Dan Keindahan Di Tempat Wisata & 23 & L5 & $\begin{array}{l}\text { Jumlah Pengurangan Kja } \\
\text { Kewirausahaan Atau Kepemilikan Bidang }\end{array}$ \\
\hline 6 & S1 & Keterlibatan Masyarakat Lokal & 24 & $\mathrm{E} 4$ & Pengelola Wisata Oleh Warga Lokal \\
\hline 7 & K2 & Dukungan Pemerintah Lokal & 25 & L2 & Daya Dukung Lingkungan \\
\hline 8 & K3 & $\begin{array}{l}\text { Dukungan Dan Kesepakatan Komunitas Dan } \\
\text { Aturan Lokal }\end{array}$ & 26 & L1 & Konservasi Perairan \\
\hline 9 & P8 & Sarana Dan Prasarana Pariwisata & 27 & E3 & Peningkatkan Pendapatan Warga Lokal \\
\hline 10 & K5 & Koordinasi Dan Kolaborasi Antar Lembaga & 28 & L4 & $\begin{array}{l}\text { Konservasi Sumberdaya Alam (Perikanan } \\
\text { Tangkap) }\end{array}$ \\
\hline 11 & P2 & Daya Tarik Wisata Budaya Dan Alam & 29 & E2 & Peningkatkan Retribusi Daerah \\
\hline 12 & P9 & Strategi Promosi Dan Pemasaran & 30 & L7 & Ancaman Bencana Alam \\
\hline 13 & P4 & Akomodasi Wisata & 31 & $\mathrm{~S} 2$ & Tingkat Kesejahteraan Warga Lokal \\
\hline 14 & P10 & Keunikan Dan Keindahan Di Tempat Wisata & 32 & L6 & Luasan Gulma Air \\
\hline 15 & P5 & Potensi Wisatawan Lokal & 33 & S4 & Konservasi Budaya \\
\hline 16 & S3 & Peluang Lapangan Kerja Bidang Pariwisata & 34 & E6 & Willingness To Pay Untuk Konservasi Perairan \\
\hline 17 & K1 & Dukungan Pemerintah Pusat & 35 & L8 & Frekuensi Turn Over/ Upwelling \\
\hline 18 & L3 & Kualitas Perairan & & & \\
\hline
\end{tabular}




\section{Kesimpulan}

Dalam upaya pengembangan ekowisata di waduk Cirata perlu menentukan variabel-variabel yang memberikan perhatian untuk keberlanjutan pada kegiatan pariwisata itu sendiri. Variabel yang telah diindetifikasi sebanyak 35 variabel dari 5 dimensi yaitu lingkungan, ekonomi, sosial, kelembagaan dan kepariwisataan. Urutan skala prioritas untuk pengembangan ekowisata waduk Cirata terdapat 1 variabel penggerak dan 21 variabel kunci di berbagai dimensi. Pada dimensi lingkungan yang harus diperhatikan adalah kualitas air, dimensi ekonomi yang harus diperhatikan yaitu peluang industry pariwisata,

Variabel yang bedasarkan tingkat pengaruh yang paling tinggi adalah kesiapan regulasi pengembangan ekowisata atau saerah tujuan wisata di waduk Cirata. Hasil studi ini merupakan dasar penentu yang kuat bagi seluruh pihak yang terlibat dalam pengambilan keputusan dan kebijakan terutama pada variabel di kuadran I dan kuadran II yang mempunyai pengaruh kuat terhadap variabel-variabel lainnya. Hasil dari pengembangan ekowisata di waduk Cirata akan diprediksi akan memberikan dampak baik secara langsung maupun tidak langsung seperti konservasi perairan, konservasi sumberdaya alam, mendukung daya dukung lingkungan, dapat mengurangi KJA, meningkatnya pendapatan warga lokal dan retribusi daerah tersebut. Diharapkan, para pengambil keputusan termasuk pemerintah daerah maupun pusat, para pelaku pariwisata dan para stakeholder untuk menentukan kebijakan agar pengembangan ekowisata Cirata berkelanjutan.

\section{DAFTAR PUSTAKA}

Anna, Z., Handaka, A. A., Maulina, I., Rizal, A., \& Hindayani, P. (2017). Biological parameters of fish stock estimation in cirata reservoir (West java, indonesia): A comparative analysis of Bio-Economic models. Biodiversitas, $18(4), \quad 1468-1474$. https://doi.org/10.13057/biodiv/d180424

Anna, Zuzy., \& Fauzi, A. (2007). Economic Loss of Pollution to Fisheries: An Economic Analysis of the Jakarta Bay Fisheries. American Fisheries Society Symposium, 587594.

Anna, Zuzy. (2016). Sustainable capture fishery management in the Ciratadam: A bio-economic modelling approach. Journal of Marine and Fisheries and Social Economy, 11(2), 161-172.

AyoPurwakarta.com. (2020, March 12). Wisata 2 Waduk Purwakarta Dinilai Semakin Potensial Bila KJA Berkurang.

https://www.ayopurwakarta.com/read/2020/03/12 /4464/wisata-2-waduk-purwakarta-dinilai-semakinpotensial-bila-kja-berkurang

CESS UNPAD. (2020). Kajian Kelayakan Penertiban dan Penataan Keramba Jaring Apung (KJA) Waduk Cirata. Kajian Kelayakan Penertiban dan Penataan Keramba
Jaring Apung (KJA) Waduk Cirata

de Almeida, M. F. L., \& de Moraes, C. A. C. (2013). Diffusion of emerging technologies for sustainable development: Prospective assessment for public policies. Journal of Technology Management and Innovation, 8(SPL.ISS.2), 228-238. 27242013000300021

Fandeli, C. (2002). Perencanaan kepariwisataan alam. Fakultas Kehutanan, Universitas Gajah Mada.

Fauzi, A. (2019). Teknik analisis keberlanjutan. Gramedia.

Haryana, A. (2020). Economic and Welfare Impacts of Indonesia's Tourism Sector Economic and Welfare Impacts of Indonesia 's Tourism Sector. IV(3), 300-311. https://doi.org/10.36574/jpp.v4i3.127

Kholil, \& Utomo, L. (2015). Strategies for Ensuring the Performance Sustainability of Cirata Reservoir Using Soft System Methodology (SSM). 5th International Conference on Environment Science and Engineering, 83(1), 73-78. https://doi.org/10.7763/IPCBEE

Kusumawardhani, A. (2017). Analisis biaya dan manfaat kelembagaan pengelolaan waduk Cirata Provinsi Jawa Barat.

Nastiti, A. S., Turni, S., \& Nugraha, B. (2018). Analisis Degradasi Lingkungan Perairan Dan Keterkaitannya Dengan Kematian Massal Ikan Budidaya Di Waduk Cirata, Environmental Degradation Analysis And Its Relationship To Mass Mortality Event OfCultured Fish In The Cirata Reservoir. 10(2), 99-109.

Nurhayati, A., \& Herawati, T. (2018). Jurnal Penyuluhan, September 2018 Vol. 14 No. 2 Analisis Faktor Adopsi Inovasi Perikanan Budidaya Karamba Jaring Apung di Waduk Cirata. 14(2), 281-288.

Pikiran Rakyat. (2018). Waduk Cirata Akan Dikembangkan sebagai Kawasan Wisata. 1. https://www.pikiranrakyat.com/bandung-raya/pr-01304530/wadukcirata-akan-dikembangkan-sebagai-kawasan-wisata

Prathama, A., Nuraini, R. E., \& Firdausi, Y. (2020). Pembangunan Pariwisata Berkelanjutan Dalam Prespektif Lingkungan (Studi Kasus Wisata Alam Waduk Gondang Di Kabupaten Lamongan). Jurnal Sosial Ekonomi Dan Politik, 1.

Purwanto, B. H., Suryadi, S., \& Sunarya, P. A. (2016). The Environmental Friendly Economic Creative Model Towards The People Around The Resevoirs Of Cirata The Province West Java Indonesia. International Journal of Applied Business and Economic Resaech, 14(11), 7935-7952.

Ruhanen, L., Moyle, C., Moyle, B., Ruhanen, L., Moyle, C., \& Moyle, B. (2018). New directions in sustainable tourism research. https://doi.org/10.1108/TR-12-20170196

Soemarwoto, O., Roem, C. M., Herawati, T., \& Pierce, B. A. C. (1990). Water quality suitability of Saguling and Cirata Reservoirs [West Java, Indonesia] for development of floating net cage aquaculture [1990]. PLN-IOE-ICLARM, 18-111. https://agris.fao.org/agrissearch/search.do?recordID=PH9110927

Sunarya, R. (2020, December 17). PLTS Terapung di Waduk Cirata Terbesar Se-Asia Tenggara. Media Indonesia.

Sutjinurani, T., \& Suharyanto. (2016). Analisis Daya Tampung Beban Pencemaran Air Dalam Pengelolaan Kegiatan Budidaya Ikan Intensif 
(Studi Kasus: Keramba Jaring Apung Waduk Cirata). 22(41), 93-103.

TIES. (2015). What Is Ecotourism? https://ecotourism.org/what-is-ecotourism/

TM Pratiwi, N., Hariyadi, S., Bagoes Soegesty, N., \& Yuni Wulandari, D. (2020). Penentuan Status Trofik Melalui Beberapa Pendekatan (Studi Kasus: Waduk Cirata). Jurnal Biologi Indonesia, 16(1), 89-98.

https://doi.org/10.47349/jbi/16012020/89

Weaver, D. (2001). Ecotourism as mass tourism: Contradiction or reality? Cornell Hotel and Restaurant Administration, 42(2), 104-112. 